\section{British VAT blocks loan of Japanese computers}

Tokyo \& London. A bizarre application of Britain's value added tax (VAT) may scuttle a loan from Japan to Imperial College in London of two component computers from the fifth-generation computer system developed by the Institute for New Generation Computer Technology (ICOT) in Tokyo.

ICOT has offered to provide two $¥ 10$ million (US\$80,000) Personal Sequential Inference (PSIs) machines free. ICOT would like to encourage worldwide development and application of its fifth-generation computer, in which Japan has invested more than $¥ 50,000$ million over the past 11 years. But under VAT rules, either the college or ICOT would have to pay VAT of $¥ 3.4$ million $(£ 17,500)$ and customs duties of $¥ 900,000$ on the machines.

This is not the first time VAT has hampered attempts by Japan to provide support for British research (see right). In 1991, the institute offered to lend David Warren of the University of Bristol the two PSIs and the necessary software. ICOT and Warren planned to pay the VAT bill out of a research grant from the Department of Trade and Industry (D'TI). However, the DTI wanted the university to get half of the amount from British companies and would not allow ICOT's contribution to count towards this. When the university was unable to meet the DTI's requirements, "to our great disappointment" the deal fell through, says Kazuo Narita, managing researcher of ICOT.

Last June, ICOT received another proposal from John Darlington and Keith Clarke has to be given up". Narita says. of Imperial College, London, both of whom had been involved in assessing the fifthgeneration project. They have suggested overcoming the VAT problem by making the loan through the Imperial College Computing Forum, which would then lend the computers to the university. As a VATregistered organization requiring the tax to be paid on subscriptions received from private companies which are members, the forum is in a position to reclaim any VAT paid on the Japanese computers.

However, the refund could be delayed, arriving too late to be used for research. Although Clarke says that this temporary shortage could be recouped from the corporate subscriptions paid into the computing forum, Narita thinks that any arrangement for the current financial year "unfortunately

ICOT has provided PSI machines to the National Institutes of Health (NIH), Argonnne National Laboratory and the University of Oregon in the United States and to the Australian National University. Some of the machines, for example those at $\mathrm{NIH}$, have not been put to much use because they are difficult for non-experts to handle (see Nature 356, 273; 1992), but ICOT has had "absolutely no problems" with tax or import duties in the United States or Australia,

The Japanese institute plans to make a third attempt at cooperation with Britain in the next fiscal year (starting on 1 April).

David Swinbanks \& David Dickson

\section{Meetings on British science}

NATURE is organizing two one-day public meetings to discuss proposals for the forthcoming white paper on the organization of British science, in Edinburgh and London.

On Friday 19 February, there will be a meeting in Edinburgh, jointly sponsored by the Edinburgh International Science Festival. The speakers will be Professor David Glover (University of Dundee), Sir Graham Hills, Professor J Maxwell Irvine (University of Aberdeen) and Professor David Wallace (University of Edinburgh). The meeting will be at the Queen Mother Conference Centre, Royal College of Physicians, 9 Queen Street, Edinburgh, and will start at 9.30 a.m.

Admission will be by ticket, free of charge, obtainable from Bruce Durie, Edinburgh International Science Festival, 1 Broughton Market, Edinburgh EN3 6NU. Coffee and tea will be provided. There will also be a sandwich lunch for those who want it, at a cost of $£ 5$ : please send a cheque, made out to the Edinburgh International Science Festival, with your ticket application.

On Friday 19 March, there will be a meeting at 9:30 a.m. in London at the Royal Society, 6 Carlton House Terrace, SW1. The speakers will include Sir Eric Ash (Rector, Imperial College London), Professor Michael Brady (University of Oxford) and Sir Mark Richmond (Chairman, Science and Engineering Research Council).

Admission will be by ticket, free of charge, obtainable from Mary Sheehan, Nature, 4 Little Essex Street, London WC2R 3LF. Coffee and tea will be provided. There will also be a sandwich lunch for those who want it, at a cost of $£ 5$ : please send a cheque, made out to Nature, with your ticket application.

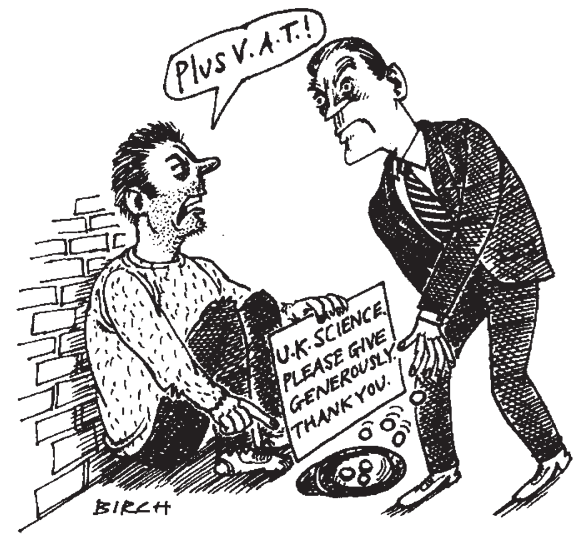

\section{UK muon source given exemption}

Tokyo \& London. ICOT is not the first Japanese organization to face a VAT bill for providing support to British research. The Institute of Physical and Chemical Research (RIKEN) near Tokyo thought that it might have to pay about $£ 2$ million (US\$3.2 million) after agreeing to invest $£ 15$ million in Britain's Rutherford Appleton Laboratory (RAL) to build and run a pulsed muon source. RIKEN was able to avoid most of the VAT only by calling the facility a 'gift' from the Japanese government.

In 1990, RIKEN and RAL, with the blessing of the British government, agreed to construct a muon source that would tap RAL's powerful pulsed proton beam. Construction and operating costs would be paid by Japan's Science and Technology Agency (see Nature 354, 98; 1991).

Late in 1990, Japanese and British officials realized that they faced a bill of about $¥ 400$ million from the British Treasury and customs for VAT (17 per cent) and customs duty (7-10 per cent) on the $¥ 1,600$ million ( $£ 8.3$ million) cost of construction of the facility, which RIKEN planned to build in Japan and transport to Britain. Such a tax bill would have caused "severe damage" to the joint project, says Katsutoshi Yasufuku, director for international cooperation at RIKEN.

Plans were altered so that some of the heavy equipment, such as shielding, costing about $¥ 600$ million, would be built in Britain. That would avoid some import duties, but not VAT. Finally, in November, most of the construction costs were exempted, as was the equipment being supplied by Japan, leaving a tax of $¥ 50$ million on British construction materials.

The special concession on import duty was granted on the grounds that the equipment was a gift from the Japanese government and because the project is for nonprofit, scientific purposes. But it seems unlikely that this procedure will be applied to the case of ICOT (see left above).

David Swinbanks \& David Dickson 